upon?' 9. The doctrine that all attention is volitional and that all intensity quality in sensation is in its origin volitionally achieved, would be much better expressed by maintaining the current distinction between 'reflex' and voluntary attention, and then adopting some general term like the current 'motor-process' to express the active process of 'achieving' all the way through (228). The confusions into which Wundt has fallen in his doctrines of attention by this same procedure might be a warning against calling the struggle of the amœba away from pain-conditions 'volitional.' ro. Object and subject-cognition are ' coincident in their origin' (252); and since sensation is cognition, all sensation involves self-sense. Mr. Stanley here seems to confuse pleasure and pain values with sense of their value for a self. He is led into it by his doctrine (criticised above) that pleasure-pain is represented as conscious end. II. The insistance that emotion is genetically stimulant to useful activities and not result of them is justified (360) ; but only on Mr. Stanley's view that emotion is intrinsically pleasure-pain. I can not see any way to avoid this claim that pleasure-pain-feeling is the dynamogenic factor all the way through. I2. Interesting discussion of play (364ff).

I have no space to speak of the author's interesting chapters on $A s-$ thetic and Ethical Emotion. J. M. B.

\title{
ETHICAL.
}

Studies in Character. S. Bryant. New York, Macmillan, 1894. (\$1.50.)

Hedonistic Theories from Antippus to Spencer. JoHn Watson. New York, Macmillan, 1895. (\$1.75.)

Mrs. Bryant's Essays are grouped under the heads 'Ethical' and 'Educational.' None the less there is a decided unity of method and point of view running through all of them. The ethical essays carry educational implications throughout, and it is the ethical side of education which commands Mrs. Bryant's attention. It is to be hoped that the book will attain a wide reading in the educational community. It is a book that does not shock one's intellectual self-respect, which is more than can be said of many professedly pedagogical treatises; and it utilizes in an unobtrusive, but none the less effective, way very much that is best in current ethical and psychological writings. Mrs. Bryant is at home in what is being said and discovered in the vital places of current discussions-another mark of emi- 
nent distinction from much of what passes as pedagogical contributions. Systematic in outer form, being a collection of essays, the book is not; systematic in unity of conception and method the book is, much more so than many more pretentious treatises.

In dealing with such topics as 'My Duty to thy Neighbor,' 'Friendship,' 'Soundness of Intellect,' etc., one perhaps could be brilliant only at the expense of sanity, and original only by leaning towards eccentricity, and the originality of sincerity (which, as Mrs. Bryant quotes Carlyle is the real originality), Mrs. Bryant possesses. However this may be, there is a tendency at times to fall into a certain explicitness of classification and definition that makes long continued reading an impossibility. A few pages are suggestive; two or three chapters of it load one with the feeling of assisting in the laying out of the corpse of the moral universe. As Professor James has remarked about too much descriptive psychology there are many things which it is highly interesting to experience, but a little tedious to be reminded of in too much detail and with too explicit a touch after we have been through them. Perhaps only Aristotle at his best, and the French moral essayists with their capacity for unexpected epigram and their ability to flash upon the reader the ironical reverse of their own definitions, have ever been at home in this region or moral description.

As to the implied ethical doctrine of the book, it is upon the whole, the idealistic interpretation of the conception of self-realization, vitalized for educational purposes with considerable concrete psychology regarding the motor tendencies of ideas and concrete insight into individual temperaments and types. I cannot forbear from pointing out that while in her ethical doctrine Mrs. Bryant conceives the 'ideal' to be perfection located at a remote goal; for practical purposes, she, like all other perfectionists, gets down to approximate ideal, which is the right functioning of present powers, or the relating of conditions of a present situation. The same contradiction occurs when Mrs. Bryant is getting at ideals from a psychological standpoint. The theory implied in practice is so certain to be more adequate than theory set up as theory of practice.

There appears to me also to be a regrettable tendency in Mrs. Bryant to over-emphasize the personal or immediate, direct side of conduct-devotion to persons, whether one's self or somebody else, instead of devotion to work, to action and to persons, whether one's self or others, indirectly through their implications in activity. But so far as there is any concensus of ethical doctrine on this point, I 
suppose it is with Mrs. Bryant rather than with the reviewer; and, as the point is too big for discussion in a review, the matter must go as a personal regret and dissent. All this direct moral devotion to persons, I believe can end only in useless complications, weariness of flesh and spirit and contradictions between our aspirations and our accomplishments, both in theory and in practice.

Professor Watson publishes his criticism of hedonism 'as a needful supplement to the ethical part of his [my] Outlines of Philosophy.' His method of criticism is, as indicated in his title, historic. It is historical types, rather than actual historic continuity, however, which Mr. Watson deals with; his authors being Aristippus, Epicurus, Hobbes, Locke, Hume, Bentham, John Stuart Mill and Spencer; about one-fourth of the book being devoted to the last named.

After discussing the influence of the Sophists, Aristippus is considered as the type of naive and, in one sense, the only consistent hedonism-the seizure of the pleasure of the present moment. Professor Watson points out a psychological contradiction contained in the idea of seeking momentary pleasure; seeking for pleasure introduces struggle and pain; pleasure as pleasure comes and is enjoyed without being sought. The doctrine is also shown to involve an essential misreading of human nature, ignoring the simple fact of experience that men seek active ends in which undoubtedly they anticipate and find pleasure, rather than pleasure as such. Epicurus enlarges and, in an objective sense, rationalizes the momentary, transitive end of Aristippus in introducing the idea of the greatest pleasure on the whole as an end; but as Professor Watson points out, at the expense of hedonism, virtually substituting a state of contentment for the ideal of pleasure; and contentment, in turn, involves its own peculiar self-contradiction, since to make the attainment of individual contentment the ideal is to throw everything back upon individual temperament, and thus deify lawlessness. Hobbes generalizes the hedonistic conception still further; Aristippus simply ignored the state; Epicurus was for getting along with it with the least possible trouble; Hobbes will turn the whole social organization into a means of bringing pleasure to the individual. ${ }^{3}$

1 While I hesitate to differ from Prof. Watson on a historical point, this statement as regards Hobbes seems doubtful. Perhaps Hobbes ought in logical consistency to have taken this view; but as matter of fact he seems to me to throw all the emphasis on the substitution of the end of the sovereign for that of the individual; and his whole political reasoning to be a back-handed way of saying 
Locke represents a consistent inconsistency-a philosophy of compromise. His intentions are good; his performance poor. He intends to assert freedom, but he holds that the strongest uneasiness determines the will, and uneasiness is simply the desire for the pleasure that is strongest. He intends to uphold the objectivity of moral distinctions, and defines the good as that which is conformable to law; but when he states how law lays hold on the individual he falls back on the pleasures got by obedience and the pains suffered through disobedience. Hume is as uncompromising as Locke the reverse. Pleasure is the sole motive, and reason can never be a motive; its sole office is to serve the feelings. With Hume the hedonistic logic may be said to have become explicit and self-conscious. The self being only a bundle of feelings, there is naught but feeling to seek or avoid, or by which to seek or avoid.

With Hume the logical evolution of hedonism ceases; since him we have only recurrences to earlier types, or else its ennobling through the introduction of ideas non-hedonistic in character. Bentham in a way went back to Hobbes, only with great practical interest in social reform which lead him to introduce elements irreconcilable with hedonism, while Stuart Mill can be made consistent only by ininterpreting his practical views from the standpoint of an idealistic theory. The examination of Mr. Spencer takes up his ethical doctrine both in its hedonistic psychology, its evolutionary aspects and the relation of one of these to the other, with a view to showing that Mr. Spencer's general formula of evolution throws no light on moral conduct; that his psychology destroys the reality of obligation, and does not justify the transition from egoism to altruism; while the idea of a completed life and completed society held up as the goal from the side of evolution have no special coherence with the ideal of pleasure set up on the analytic side.

Philosophic exposition is at its best as to style in this book of Professor Watson's. I could with difficulty name another book which might at once command so thoroughly the respect of the specialist and receive comprehension by the layman as does this lucid, direct piece of exposition and criticism. It may be of service to teachers of ethics to point out that the expositions of the various authors, mainly

that since men live in society they must regard the social end before the individual end; and that if they lived in a state of nature, while each might then follow his own selfish end, yet such a state would be self-contradictory. In other words, Hobbes' psychology and his sociology contradict each other flagrantly, instead of the latter being an instrument as regards the former. 
in the authors' own words, are well proportioned, condensed and accurate, and, in some cases, the best available substitutes for a perusal of the original texts, and in all cases a helpful accompaniment of such perusal.

The book seems to me to close the case, on the polemic side, as regards hedonism. Undoubtedly we shall go on having arguments both for and against hedonism, but the interest seems about done with. The rise of a new psychological method and of a new sociological point of view and body of facts have presented new problems and shifted the focus of attention. These indirect influences have probably done quite as much as more direct criticism in making hedonism a played-out standpoint. Just because Prof. Watson's book has accomplished its task so thoroughly, one lays it down with a feeling of what has not been accomplished, and of what constitutes the next task-the discussion of hedonism from the historic standpoint, in the evolutionary sense. We do not need longer to contend with hedonism as a present foe, and consequently we want to comprehend it more thoroughly as a manifestation-comprehend it not in terms of itself, but in terms of the social and intellectual conditions which have given birth to it, to see what it really means when so interpreted. From the historic evolutionary standpoint, there has been the same inner necessity, in the logic of growth, for the appearance of these hedonistic systems as there has been for that of any transcended animal or political form of life. What is that inner necessity?

JoHN DEwRY.

\section{LESIONS OF THE CORTICAL NERVE CELL IN ALCOHOLISM.}

Experimentelle Untersuchungen über die Veränderungen der Ganglienzellen bei der acuten Alcoholvergiftung. HEINRICH DeHı, Centralbl. für Nervenheilk. u. Psychiat. V. I13-1 18. Studies on the Lesions produced by the Action of certain Poisons on the Cortical Nerve Cell. I. Alcohol. Henry J. BerkLey. Brain, LXXII. 473-496.

The two articles above mentioned have made an attack upon one of the least worked fields of nervous pathology opened up by the advance of the last few years in the methods of preparing and staining 